\title{
SELECTION OF AGRICULTURAL LAND FOR MULTIFUNCTIONAL AGRICULTURE
}

\author{
Nebojsa Novkovic ${ }^{1}$, Sandor Somodjii $^{2} \&$ Milenko Matkovic $^{3}$ \\ ${ }^{1}$ Faculty of Agriculture, Department of Agricultural Economics and Rural Sociology, University of Novi Sad, \\ Serbia,nesann@polj.uns.ac.rs \\ ${ }^{2}$ Professor emeritus \\ ${ }^{3}$ Student
}

\begin{abstract}
The modern concept of rural development implies the use of agricultural resources, primarily agricultural land, for other (nonagricultural) activities besides its agricultural purpose. The integral aim of this concept of rural development is the maximization of economic results, besides the sustainable development of rural areas, environmental protection and the production of strategic (staple) agricultural products.

The objective of this paper is to define the general, theoretical, quantitative model for the determination of the size and quality of agricultural land which, considering the above-mentioned demands (criteria), is optimal for the utilization in agricultural production in certain regions. The remaining agricultural land would be available for the non-agricultural purposes.

The economic optimal model for the selection of agricultural land in the traditional agriculture is the model of linear programming. The criteria of the land selection for traditional agriculture are the economic effectiveness (measured by net income or by gross national product) and the economic efficiency (measured by the production economy). The maximum economic effectiveness is determined by the standard method of linear programming and the maximum economy by the method of broken linear programming. The solution of compromise can be determined by multi-criteria programming, based on the minimum differences.

The limitation groups in the mentioned variations of the model are: limitations of production quotas of agricultural products, minimum quantities of staple agricultural products, limitations of processing plants in a region (minimum and maximum), limitation of crop rotation, limitations of the needs in animal husbandry for bulky forage and limitations of agricultural land according to various types of utilization. By quantitative defining of the structure and size of agricultural land for traditional agriculture, "the surplus" and structure of agricultural land available for non-agricultural purposes is automatically determined.
\end{abstract}

Key words: agricultural land, optimization model, use for non-agricultural purpose

\section{Introduction}

One of the harmful it not even dangerous irrationalities of man's behaviour is that concerning his relation and attitude toward his environment. In economy, it is usually the shortterm changes causing easily recognizible manifestations that attract professional attention most. In economy, it is usually the short-term changes causing easily recognizible manifestations that attract professional attention most. At the same time the slow, almost unnoticable changes are neglected though having some very dangerous and quite often irreversible effects. Such are the changes of the quality of soil, subterranean water there are various taxes for the use of artificial objects, anybody can use (according to his own criteria, paying no special tax) land, water and air as economic resources. These resources are available without payment; the costs of their maintenance most often are not causally related to their use and to profiting from them.

To put it figuratively, we behave like a man who carefully cures his unpleasant cough, but proceeds smoking and gives no attention to the slow, long-term changes in his body that can easily have cancerogenous consequences. Quite comparable is the way we treat land resources.

This paper is aimed at pointing to some of the consequences of the non-rational use of agricultural land. Several methodological problems are also discussed concerning the selection of agricultural land the use of which is economically unjustifiable in conditions of agricultural commodities production.

\section{Agricultural Land use and food production - general problems}

Borojevic was undoubtedly right arguing that "Our major natural resource is land and we are still not conscious of the fact that there isn't much agricultural land and that each year we easily lose hundreds of hectares" (2).

In the history of mankind there were various examples of fertile soils destruction and the related disappearance of 
human civilizations. It would be enough to mention an alarming process in contemporary Africa: during the last 50 years some 650000 square kilometers of potentially arable land in the south of Sahara has turned into deserts (4). Until recently, gigantic dams were considered a sort of sacred symbols of African progress. However, scientific research and measurements have contributed to the conclusion that these "super-dams" cause more damages than benefits. The Egyptian Asian has for ever taken away 400000 ha of arable land. The as combo dam in Ghana caused the inundation of an area almost as large as Lebanon, with actually most fertile fields in valleys by the Volta. The change of this river's course has affected the Atlantic Ocean streams which consequently resulted in destruction of some $100 \mathrm{~km}$ of seashore. Besides, huge dams have also caused various social and economic problems, like disappearance of many villages, ruining of small producers, etc. (1).

Unfortunately, there is negative example in Middle Europe. Well-known is a problem of Bös-Nagymaros, with all consequences what already manifested.

Agricultural land has also been continually lost due to some other needs of the mankind. According to Madas (6), "World population is, at the present tempo of increase, doubled each 35 years. This increases the requirements for residential acreages, which are now 0.08 ha per inhabitant (including apartment, roads, long/distance power lines, water supply, etc.). The 3,2 billion hectares which, speaking theoretically, can be used will be reduced to more one billion by the year 2070 - which probably won't be enough to meet the needs for rood".

On the other hand, the nutrition problem has always generated an immense pressure on global political relations. Even in 1965 FAO began to monitor the international situation concerning agriculture and nourishment. Under the influence of FAO 's findings, in early 1970 's the prognostic activities were given rise to, so that quite a number of scenarios were lunched concerning possible movements in providing enough food for mankind. These scenarios were mostly of the Malthusian type, as it is the case with the papers of Meadows and his group, on the limits of growth (7), of Mesarovic, Heilbroner, Erlich, Forrester (9). Even the authors who did not approve of their concepts, like Hermann Kahn, several Soviet authors, the Bariloche group did admit the existence of a final limit of growth on the Earth. This explosion of dark visions has probably contributed a lot to a (psychological) pressure toward appropriate measures on the global level. After the 1974 UN conference on food some major changes occurred resulting in a controversial situation on the global level. Famines are still common in many (mostly rural) areas, and the impression is still strong that Lowdermilk (5) was right arguing that "For 7000 years man has been looking for the ways toward a better life on this planet, which in fact has been a race with the famine, in which the winner is still unknown". On the other side, there is an abundance of food and a real war in the international markets.

According to the New Farm's data, financially supported agricultures of 25 highly developed countries receive around
$\$ 160$ billion through various subventions. In these countries, as stated by Demmler (3), the share of agriculture in total national investments is higher than it is in gross national income, in percentages. Hence, from the viewpoint of the Portfolio philosophy (cash investments) it can be presumed that in many countries agriculture is viewed as a profit-centre with a promising future. It seems that such an attitude is recognizable even in some of the countries traditionally faced with famine.

In general, the EEC countries have met their food demands and have even produced certain amounts of surpluses. According to Nemeth (8), in 1981 their demands for plant and animal products were already met by $114 \%$ and $105 \%$, respectively.

All this suggests the conclusion that global interests of the mankind, in respect of agricultural land maintenance and the long/term food supply have been seriously affected. On the other hand, however, the developed countries are facing the problems of food overproduction, the necessity of reducing the arable land acreages, and soil conservation.

\section{Previous researches and a possible solution}

Previous researches focused mostly on the problems of production functions of production. By using different types of production functions the optimal combinations of fixed and variable plant production factors were searched for, i.e. the researches were aimed at defining the optimal intensity level. Analyses of production results by method of production functions have also shown a great variability of conditions, production results, production elasticity levels, justifiable or unjustifiable use of variable factors. By methods of linear programming, most often with several criteria of optimality, the problems of optimal production structures for various conditions were analyzed. However, until present the task of analyzing the optimal and, on the other hand, unjustifiable use of soil as a fixed production factor in plant production. Gradual introducement of market economy and more direct impact of market regulations will soon impose the problem of agricultural land use - in the first place for the purposes of regional development planning and urbanization.

Therefore a question is what agricultural land can be and on rational basis should be definitely excluded from production, to be used for other, non-agricultural purposes?

The problem of transformation of agricultural land for non-agricultural purposes is not only the question of ecological and economic significance. In the first place it is a strategic question since each national economy shows the tendency of food production self-sufficiency. In the case food commodities' surpluses are not the tradable ones, or the trade is not rationally justifiable, the question is: what agricultural land capacities should be used for nonagricultural purposes, according to the criteria of economic justification? It should clearly be the worse quality soils; however, what areas precisely and what acreages - that is not so easy to decide on 
grounds of free estimations. The fact that various crops react differently on different types of soils make this problem even more complex.

The starting point in a model to be used for defining the potential "surpluses" of agricultural land are $\mathrm{de} \mathrm{m}$ a n $\mathrm{d}$ s for particular quantities of particular agricultural products. The term "demand" includes self sufficiency and the possibility of export. In the long run, the annual quantities of particular agricultural products can be approximately defined which provide for self - sufficiency and offer good prospects of export (production Quota).

Since food production is the function of two parameters acreage and average yield - the question is imposed of defining the economically optimal level of production intensity, and hence the economically optimal yield to aim to. However, the economically optimal yield is not a fixed category but depends on input/output prices parity which is strongly influenced by market interdependences and is therefore a changeable factor.

Under assumption of relatively stable agricultural input and output prices parity within the framework of agriculture, the problem of surpluses determination of agricultural land is possible formulate with multilevel linear programming model.

Objective function in this model will be maximum economic effectiveness (in terms of maximum gross margined) and maximum efficiency (in terms of maximum economy) of total national agriculture, like two basic economy criteria's, as absolutely and relatively business performance (10).

By compromise solution of model, on the basic alike respect of both criteria, is possible to define such production structure which will be (under available conditions) in the most degree simultaneously rationally exploit available agriculture production powers and realize high returns, for propose degree of production structure.

For getting of compromise solution in the preliminary steps it is necessary optimization on the basic of particular criteria.

Mathematical interpretation of multi criteria strategic model for definition the potential surpluses of agricultural land are:

$1^{\text {st }}$ step: Optimalization on the base of maximum effectiveness

1) Objective function

$$
\sum_{\mathrm{i}=1}^{\mathrm{m}} \sum_{\mathrm{j}=1}^{\mathrm{n}} \mathrm{GM}_{\mathrm{ij}} \mathrm{S}_{\mathrm{ij}}=\mathrm{GM}_{(\max )}
$$

2) Limitations of products - production quotas

$$
\sum_{j=1}^{n} Y_{i j} S_{i j}=Q_{i}
$$

3) Biotechnical limitations (crops rotations)

$$
S_{i j} \leq p_{i j} S_{j}
$$

4) Land limitations

$$
\sum_{i=1}^{m} S_{i j} \leq S_{j}
$$

$$
\begin{aligned}
& \text { Where is: } \mathrm{i}=1(1) \mathrm{m} \mathrm{m}=\text { number of crops } \\
& \mathrm{j}=1(1) \mathrm{n} \mathrm{n}=\text { number of types of soil } \\
& \mathrm{GM}_{\mathrm{ij}} \quad=\text { gross margin of "i" crop on soil type " } \mathrm{j} \text { " } \\
& \text { for optimal level of intensity ( } € \text { ha) } \\
& \mathrm{GM}(\max )=\text { Agricultural maximum gross margin }(€) \\
& \mathrm{S}_{\mathrm{ij}} \quad=\text { Acreage under "i" crop on the " } \mathrm{j} \text { " type } \\
& \text { of soil (ha) } \\
& \mathrm{Y}_{\mathrm{ij}} \quad=\text { Optimal yield of "i " crop on the soil } \\
& \text { type "j" (t/ha) } \\
& \mathrm{Q}_{\mathrm{i}} \quad=\text { Required quantities of " } \mathrm{i} \text { " product }(\mathrm{t}) \\
& \mathrm{p}_{\mathrm{i}} \quad=\text { Maximal participation "i" crop in } \\
& \text { production structure } \\
& \mathrm{S}_{\mathrm{j}} \quad=\text { Available acreage of " } \mathrm{j} \text { ” soil (ha) }
\end{aligned}
$$

1) Objective function

$$
\begin{aligned}
& \sum_{i=1}^{m} \sum_{j=1}^{n} V_{i j} X_{i j}=E P(\max ) \\
& \text { 2) } \sum_{i=1}^{n} Y_{i j} X_{i j}-q Q_{i}=\varnothing \\
& \text { 3) } X_{i j}-q_{i j} S_{j} \leq \varnothing \\
& \text { 4) } \sum_{i=1}^{m} X_{i j}-q S_{j} \leq \emptyset
\end{aligned}
$$

5) Additional limitation of costs

$$
\sum_{i=1}^{m} \sum_{j=1}^{n} V_{i j} X_{i j}+q F C=1
$$

Where is:

$$
\begin{aligned}
& \mathrm{VP}_{\mathrm{ij}} \quad=\text { Value of production" } \mathrm{i} \text { " crop on soil } \\
& \mathrm{EP}(\max )=\text { Maximum economy of production } \\
& \mathrm{X}_{\mathrm{ij}} \quad=\text { Independent variable in the model } \\
& \mathrm{VC}_{\mathrm{ij}} \quad=\text { Variable costs "i } \mathrm{i} \text { " crop on soil type " } \mathrm{j} \text { " } \\
& \text { for the optimal level of intensity ( } € \text { ha) } \\
& \mathrm{FC}=\text { Total fixed costs of agriculture (or total } \\
& \text { capital assets value) ( } € \text { ) } \\
& \mathrm{q}=\text { Additional variable }
\end{aligned}
$$

Acreage of particular crops, in this case, can be determinate after saluting of model from this relation:

$$
\bar{S}_{i j}=\frac{\bar{X}_{i j}}{q}
$$


$3^{\text {rd }}$ step: Compromise solution

1) Objective function $\mathrm{d}_{1}+\mathrm{d}_{2}=\mathrm{D}(\mathrm{min})$

2) $\sum_{j=1}^{n} Y_{i j} X_{i j}-q Q_{i}=\varnothing$

3) $\mathrm{X}_{\mathrm{ij}}-\mathrm{qp}_{\mathrm{i}} \mathrm{S}_{\mathrm{j}} \leq \varnothing$

4) $\sum_{i=1}^{m} X_{i j}-q S i j$

5) $\sum_{i=1}^{m} \sum_{j=1}^{n} V_{i j} X_{i j}+q F C=1$

6) Additional limitation of difference from the maximal efficiency

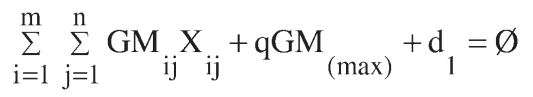

7) Additional limitation of difference from the maximal efficiency

$$
\sum_{i=1}^{m} \sum_{j=1}^{n} V_{i j} X_{i j}+d_{2}=E p_{(\max )}
$$

Where is:

$\mathrm{d}_{1}=$ difference from maximal effectiveness

$\mathrm{d}_{2}=$ difference from maximal efficiency

$\mathrm{D}=$ total minimum difference from both criteria

Where also, like preliminary case, is current relation:

$$
\bar{S}_{i j}=\frac{\bar{X}_{i j}}{q}
$$

\section{Conclusion}

By solving this general problem of compromise broken programming (with food demands satisfaction) from relations of the in equation of limitation groups under 4), we obtain the information about reserve of particular soil type resources which are not included in optimal production structure. These reserves indicate what agricultural land acreages can potentially be used for nonagricultural purposes.

In this case we deal with a methodological, general theoretic model the operationalization of which requires a number of parameters such as yield oscillations, deviations of optimal yields from the average ones, dynamics of movements in particular products demands, population growth, technical-technological progress in agriculture, etc.

In spite of its generality and insufficient precision, the presented model offers the potential framework and points out (alt least in general terms) the structure and acreage of agricultural land which is sooner or later supposed to be used for a changed purpose.

This kind of application of an optimization model doesn't require the local optimum of a particular producer, but a global optimum of a national or regional level. That is why an adequate strategic selection of parameters and aspects of logistic chains of production and distribution is automatically required. The neglecting of global environment parameters and an overestimation of the significance of those concerning local environment can easily lead to sub-optimizations.

\section{Literature}

Dolou, J.H., Norton, R.D.(1987): Chac, A Programming Model of Mexican Agriculture, AJAE, Februar

Krasnić, T. (2004): Model za optimiranje strukture povrtarske proizvodnje, doktorska disertacija, Poljoprivredni fakultet, Novi Sad

Lučić, Đ. (1997): Modeli intenziviranja proizvodnje u poljoprivrednim preduzeæima, doktorska disertacija, Poljoprivredni fakultet, Novi Sad

Novković, N. (1988): Structure of Farming Production in Agricultural Firms: An Optimalization Model, Zbornik radova 17. seminara EAAE, Debrecen (266-275)

Novković, N., Šomoði, Š. (1991): Multiple Criteria Programming Implementation in the Integral Production Planning in the Agricultural Enterprises of Yugoslavia, Zbornik radova 20. konferencije CIRET, Budapest

Novković, N., Šomoði, Š. (1993): Multi-criteria Model for Optimal Regional Planning of Agriculture, Zbornik radova 2. balkanske konferencije o operacionim istraživanjima, Thessaloniki (697-705)

Paunović Naða (2004): Formulisanje modela strateškog planiranja poslovnog sistema u agrobiznisu, magistarska teza, Poljoprivredni fakultet, Novi Sad

Pušičić D. (2003): Logistièki model za planiranje organizacije transporta, magistarska teza, Poljoprivredni fakultet, Novi Sad

Rajić, Z. (2002): Model za optimiranje strukture proizvodnje industrijske klanice, doktorska disertacija, Poljoprivredni fakultet, Novi Sad

Rodić Vesna (2001): Model za optimiranje razvoja poljoprivrede i prehrambene industrije, doktorska disertacija, Poljoprivredni fakultet, Novi Sad 